\title{
PENGARUH TINGGI DAN KERAPATAN UNGGUN PADA KUALITAS PEMBAKARAN GAS PRODUSER DARI GASIFIKASI SKALA RUMAH TANGGA
}

\author{
Anton Irawan*, Hafid Alwan, Faroukiyah Mustika \\ Kelompok Keahlian Konversi Energi \\ Jurusan Teknik Kimia, Universitas Sultan Ageng Tirtayasa \\ Jalan Jenderal Soedirman Km. 3 Cilegon, Banten 42435 \\ Email: anton@ft-untirta.ac.id
}

\begin{abstract}
Abstrak
Peningkatan kebutuhan energi menyebabkan minyak bumi menjadi mahal dan terbatas sehingga energi terbarukan dapat menjadi solusi untuk menggantikan minyak bumi pada masa mendatang. Salah satu sumber energi terbarukan adalah sekam padi yang dihasilkan dari pengolahan padi dengan kandungan energi 3000-3500 kcal/kg sekam padi kering. Sekam padi memiliki komposisi karbon sekitar $15 \%$, volatile matter $50 \%$, abu $20 \%$, dan kandungan air 25\% sehingga sekam padi dapat dikonversi melalui proses gasifikasi. Dengan metode gasifikasi skala rumah tangga, gas produser yang dihasilkan dapat dipergunakan sebagai bahan bakar rumah tangga. Tujuan penelitian ini adalah mengamati pengaruh tinggi dan kerapatan unggun terhadap kualitas pembakaran gas produser hasil gasifikasi sekam padi. Parameter kualitas pembakaran adalah pengukuran temperatur lidah api dengan posisi tetap. Waktu tahan temperatur di atas $500{ }^{\circ} \mathrm{C}$ menjadi standar kualitas proses gasifikasi sekam padi yang dipengaruhi oleh kerapatan dan tinggi unggun sekam padi. Gasifikasi dilakukan pada kompor gasifikasi skala rumah tangga yang mampu memuat sekam padi 1000 g. Variasi tinggi unggun adalah 25, 40, dan $55 \mathrm{~cm}$ serta kerapatan unggun 85, 95, dan $105 \mathrm{~kg} / \mathrm{m}^{3}$. Hasil penelitian menunjukkan bahwa kualitas pembakaran gas produser dipengaruhi oleh tinggi dan kerapatan unggun.
\end{abstract}

Kata kunci: sekam padi, gasifikasi, gas produser, tinggi unggun, kerapatan unggun

\begin{abstract}
THE EFFECT OF BED HEIGHT AND DENSITY ON PRODUCER GAS COMBUSTION QUALITY FROM HOUSEHOLD SCALE GASIFICATION. Increased energy demand caused the crude oil to be expensive and limited so that renewable energy could be a solution of the crisis energy in the future. Rice husk that produced from rice mill had potential as energy in the rural area due to had energy content around 3000-3500 kcal $/ \mathrm{kg}$. Rice husk had proximate analysis for fixed carbon $15 \%$, volatile matter $50 \%$, ash $20 \%$, and moisture $15 \%$ so that rice husk could be converted to the gas by gasification. Gas producer that was produced by gasification can be used for household fuel. The aim of this research was to observe influence of density and height of rice husk bed to the flame of the gas producer combustion in the small scale gasification. Small scale gasification was done in gasification stove that had capacity $1000 \mathrm{~g}$ rice husk. Variations in this research were density of rice husk bed $\left(85,95\right.$, and $\left.105 \mathrm{~kg} / \mathrm{m}^{3}\right)$ and height of rice husk bed $(25,40$, and $55 \mathrm{~cm})$. Parameter of quality of gas producer combustion was holding time of the flame temperature above $500{ }^{\circ} \mathrm{C}$. The results showed the combustion quality of the gas producer was influenced by density and height of rice husk bed.
\end{abstract}

Keywords: rice husk, gasification, gas producer, bed height, bed density

*penulis korespondensi 


\section{PENDAHULUAN}

Kebutuhan bahan bakar yang semakin meningkat menyebabkan kelangkaan dalam memperoleh sumber-sumber bahan bakar. Kondisi ini telah diantisipasi oleh pemerintah dengan melakukan konversi energi dari bahan bakar minyak tanah ke bahan bakar LPG untuk penyediaan bahan bakar bagi keperluan rumah tangga. Konversi bahan bakar minyak tanah ke bahan bakar LPG merupakan konversi energi dengan sumber yang sama yaitu minyak bumi. Pada masa mendatang, kondisi ini akan menyebabkan kendala dalam penyediaan bahan bakar LPG karena cadangan bahan bakar gas yang semakin menipis. Kendala energi yang akan dihadapi oleh masyarakat perlu diantisipasi dengan penyediaan bahan bakar yang tersedia dalam jumlah banyak serta bahan bakar tersebut dimiliki oleh masyarakat di daerah yang susah mendapatkan energi. Biomassa merupakan salah satu solusi untuk penyelesaian keterbatasan energi bagi daerah-daerah yang jauh dari sumber-sumber energi konvensional.

Salah satu bahan bakar biomassa yang banyak terdapat hampir di seluruh wilayah Indonesia adalah sekam padi. Menurut Badan Pusat Statistik tahun 2010, Indonesia menghasilkan sekitar 20 juta ton limbah sekam padi atau 8000 MWe yang dapat dimanfaatkan sebagai sumber energi. Menurut Bhattacharya dkk. (1999), tidak banyak negara Asia yang memanfaatkan biomassa non-kayu untuk keperluan energi di rumah tangga karena biomassa non-kayu memiliki kelemahan mendasar. Adapun kelemahan mendasar dari biomassa non-kayu adalah densitas curah dan kandungan kerapatan energi yang rendah. Salah satu teknologi yang sesuai untuk konversi biomassa non kayu seperti sekam padi adalah teknologi gasifikasi. Gasifikasi sekam padi dipilih sebagai salah satu cara untuk memanfaatkan sekam padi dengan dasar kandungan zat terbang (volatile matter) sekam padi yang tinggi. Analisis proksimat terhadap sekam padi menunjukkan kandungan zat terbang dapat mencapai $63,7 \%$ (Sarasuk dan Sajjakulnukit, 2011). Gasifikasi biomassa merupakan suatu proses dekomposisi termal dari bahan-bahan organik melalui pemberian sejumlah panas dengan suplai oksigen terbatas (sub-stokiometri) untuk menghasilkan gas produser yang terdiri dari $\mathrm{CO}, \mathrm{H}_{2}, \mathrm{CH}_{4}$ sebagai produk utama dan sejumlah kecil arang karbon dan abu.

Beberapa penelitian tentang gasifikasi sekam padi telah dilakukan khususnya dalam skala besar untuk memproduksi gas produser yang dipergunakan untuk pembangkit listrik atau produksi zat kimia. Penelitian tentang analisis ekonomi untuk gasifikasi biomassa termasuk sekam padi telah dilakukan untuk skala 1-5 MWe (Wu dkk., 2002). Ramirez dkk. (2007) telah melakukan penelitian tentang perancangan gasifikasi sekam padi sistem terfluidakan yang dipergunakan sebagai dasar dalam pembuatan model matematika. Selain itu, Lin dkk. (1998) mengamati perubahan silica hasil gasifikasi sekam padi. Thailand telah mampu memproduksi energi skala komersial 400 MWe dengan cara gasifikasi sekam padi. Produksi dalam skala besar tersebut dimulai dari penelitian gasifikasi sekam padi skala laboratorium $50 \mathrm{~kW}$ (Sarasuk dan Sajjakulnukit, 2011).

Pemanfaatan biomassa dengan teknologi gasifikasi dapat diimplementasikan dalam skala rumah tangga dengan menggunakan kompor gasifikasi. Kompor gasifikasi sebagai teknologi aplikatif gasifikasi biomassa sekam padi adalah pengganti kompor LPG yang memiliki banyak keuntungan diantaranya dapat menggantikan $253 \mathrm{Kg}$ LPG dengan satu ton sekam padi (Belonio, 2005). Dengan kondisi ini, maka pemanfaatan sekam padi dapat mengurangi biaya pengeluaran rumah tangga, meminimalisir masalah yang ditimbulkan oleh penumpukan sekam padi yang berkontribusi besar dalam pencemaran lingkungan, dan mengurangi emisi karbon dioksida dalam udara yang dihasilkan dari pembakaran langsung sekam padi. Efisiensi yang dapat dicapai dengan teknologi gasifikasi sekitar 30$40 \%$ dan yang lebih tinggi dari teknologi kompor biasa hanya sebesar 5-15\% (Bhattacharya dan Leon, 2008). Pada penelitian ini akan digunakan kompor gasifikasi berbahan bakar limbah sekam padi dengan metode gasifikasi unggun tetap updraft.

Proses gasifikasi pada kompor gasifikasi tipe up-draft berbeda pada skala besar karena proses oksidasi berlangsung pada bagian atas kemudian turun menuju area reduksi, pirolisa, dan pengeringan (Gambar 1). Dengan posisi oksidasi pada bagian atas maka potensi gas panas masuk ke zona reduksi, pirolisa, dan pengeringan sangat 
dipengaruhi oleh kerapatan dan ketinggian unggun sekam padi. Pada penelitian ini akan dilakukan pengamatan untuk pengaruh ketinggian dan kerapatan unggun sekam padi terhadap kualitas pembakaran gas produser yang dihasilkan dari proses gasifikasi sekam padi pada kompor gasifikasi skala rumah tangga. Temperatur pembakaran gas yang dihasilkan dari proses gasifikasi sekam padi dijadikan acuan untuk mengamati kestabilan proses gasifikasi sekam padi.

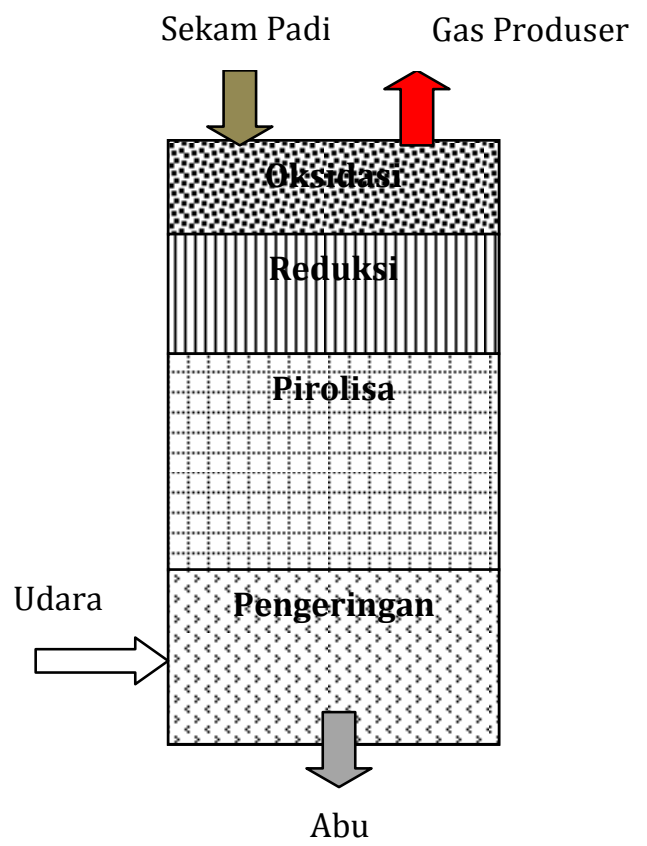

Gambar 1. Aliran padatan, udara, dan gas produser serta pembagian zona pada tipe reaktor gasifikasi up-draft

\section{METODE}

Penelitian ini menggunakan sekam padi yang diperoleh dari penggilingan padi di wilayah Banten. Kemudian sekam padi dijemur secara alami di bawah sinar matahari sekitar 12 jam untuk menurunkan kandungan air pada permukaannya (Gambar 2). Sekam padi yang telah mengalami proses pengeringan kemudian dianalisis komposisi proksimat serta kandungan energi. Hasil analisis proksimat menunjukkan bahwa kandungan zat terbang (VM) sebesar 53\% (Tabel 1). Analisis densitas curah untuk sekam padi yang digunakan sebesar $85 \mathrm{~kg} / \mathrm{m}^{3}$. Densitas curah sekam padi yang digunakan dalam penelitian ini lebih kecil dari densitas curah sekam padi yang digunakan oleh Belonio et al. (2005) antara $100-200 \mathrm{~kg} / \mathrm{m}^{3}$ serta Sarasuk dan Sajjakulnukit, (2011) dengan densitas curah $120 \mathrm{~kg} / \mathrm{m}^{3}$. Meskipun Sarasuk dan Sajjakulnukit menggunakan densitas curah yang tinggi tetapi kandungan zat terbang yang dimiliki juga tinggi sebesar $63,7 \%$ sehingga potensi gas yang dihasilkan lebih tinggi. Dengan kondisi ini maka perlu dilakukan penelitian untuk mengamati pengaruh kerapatan sekam padi dan tinggi unggun dengan menggunakan kualitas sekam padi yang lebih rendah dibandingkan sekam padi yang digunakan dalam penelitian Belonio (2005) dan penelitian Sarasuk dan Sajjakulnukit (2011).

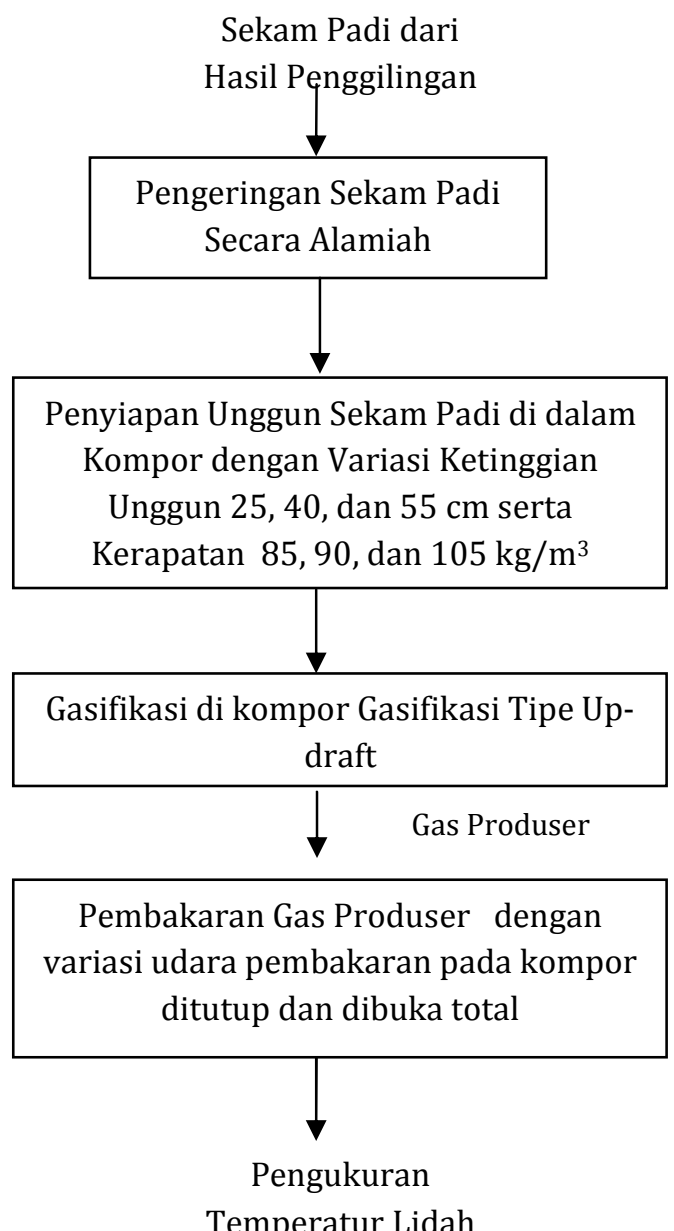

\section{Gambar 2. Diagram alir penelitian}

Sekam padi kering dimasukan ke reaktor kompor gasifikasi dengan variasi densitas unggun sekam padi 85, 95, dan 105 $\mathrm{kg} / \mathrm{m} 3$ serta ketinggian unggun sekam padi 25, 40, dan $55 \mathrm{~cm}$ dihitung dari grate kompor gasifikasi sekam padi. Gambar 3 memperlihatkan kompor reaktor gasifikasi yang digunakan dalam penelitian ini dan dikembangkan oleh Belonio (2005). Adapun 
Tabel 1. Analisa Proksimat Sekam Padi (adb \%-berat)

\begin{tabular}{ccccccc}
\hline & VM & FC & MC & Abu & $\begin{array}{c}\text { Densitas Curah } \\
\left(\mathrm{kg} / \mathrm{m}^{3}\right)\end{array}$ & $\begin{array}{c}\text { CV } \\
(\mathrm{kcal} / \mathrm{kg})\end{array}$ \\
\hline $\begin{array}{c}\text { Sampel } \\
\text { Sekam Padi }\end{array}$ & 53,23 & 12,94 & 11,39 & 22,44 & 85 & 3019 \\
\hline
\end{tabular}

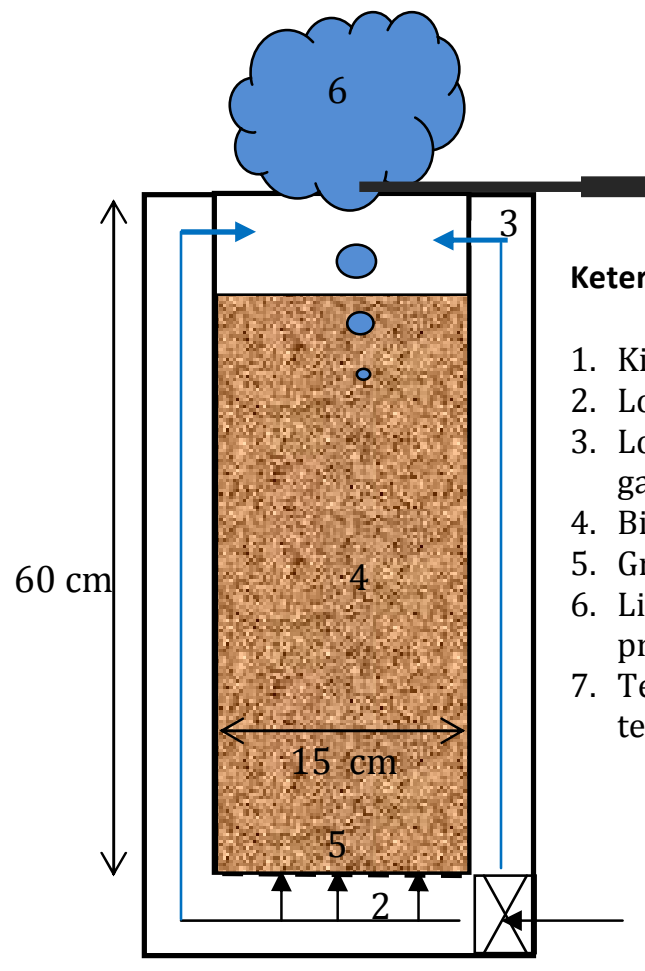

1

Gambar 3. Skema kompor gasifikasi sekam padi

alat-alat tambahan yang dipergunakan dalam penelitian ini antara lain termokopel, neraca analitik, stopwatch serta gelas ukur. Termokopel digunakan untuk mengukur temperatur nyala api selama gasifikasi berlangsung sebagai indikasi kualitas gas yang dihasilkan dari proses gasifikasi di dalam kompor gasifikasi. Gelas ukur digunakan untuk mengetahui densitas unggun. Kemudian sekam padi ditimbang berdasarkan variasi ketinggian dan kerapatan unggun sekam padi. Setelah ditimban, sekam padi dimasukkan ke kompor gasifikasi untuk dimulai proses gasifikasi. Gas produser yang dihasilkan dari kompor gasifikasi langsung dibakar dengan menggunakan penyulut kertas diatas dari unggun sekam padi. Pengukuran temperatur langsung dilakukan dengan menempatkan termokopel pada posisi yang sama untuk seluruh variasi. Lama waktu tahan (detik) untuk temperatur di atas $500{ }^{\circ} \mathrm{C}$ digunakan sebagai acuan dalam menilai kualitas pembakaran gas produser.

\section{HASIL DAN PEMBAHASAN}

Pengaruh Kerapatan Unggun Sekam Padi

Pada variasi kerapatan 85, 95, dan 105 $\mathrm{kg} / \mathrm{m}^{3}$ dengan tinggi unggun sekam padi 40 $\mathrm{cm}$ bahwa temperatur nyala api di atas $500{ }^{\circ} \mathrm{C}$ dapat dicapai pada detik ke-120 (Gambar 4). Pada kerapatan unggun $85 \mathrm{~kg} / \mathrm{m}^{3}$, temperatur nyala api yang dihasilkan lebih besar setelah detik ke-120 dibandingkan dengan kerapatan unggun 95 dan $105 \mathrm{~kg} / \mathrm{m}^{3}$. Pada kerapatan unggun yang tinggi menyebabkan udara yang disuplai dari bagian bawah (Gambar 3) sulit melewati unggun dan gas produser yang dihasilkan pada area reduksi sulit untuk melewati area oksidasi sehingga tertahan di dalam unggun. Tetapi kerapatan unggun 85 $\mathrm{kg} / \mathrm{m}^{3}$ dapat mencapai temperatur diatas $1000{ }^{\circ} \mathrm{C}$ pada detik ke-600 karena udara dan gas bakar dapat dengan mudah melewati unggun dan mencapai kondisi Lean Mixture meskipun udara sekunder ditutup. Temperatur di atas $500{ }^{\circ} \mathrm{C}$ untuk kerapatan 85 $\mathrm{kg} / \mathrm{m}^{3}$ tidak berlangsung lama karena panas 
yang dihasilkan dari oksidasi tidak dapat mengimbangi kebutuhan panas untuk proses pengeringan, pirolisa, dan reduksi sehingga temperatur pada kerapatan $85 \mathrm{~kg} / \mathrm{m}^{3}$ akan menurun pada detik ke-960. Kondisi yang sama juga dialami pada kerapatan $95 \mathrm{~kg} / \mathrm{m}^{3}$. Tetapi pada kerapatan $105 \mathrm{~kg} / \mathrm{m}^{3}$ memiliki temperatur di atas $500{ }^{\circ} \mathrm{C}$ yang lebih lama hingga detik ke-1440 dengan proses oksidasi yang menghasilkan panas yang cukup untuk mensuplai proses-proses lain yang memerlukan panas. Dengan demikian semakin tinggi kerapatan sekam padi akan berpengaruh terhadap laju combustible gas yang dapat dilihat dari profil temperatur selama proses gasifikasi berlangsung (Gambar 4). Kerapatan unggun rendah sebesar $85 \mathrm{~kg} / \mathrm{m}^{3}$ akan menghasilkan temperatur yang terus meningkat dan waktu yang relatif cepat. Sedangkan kerapatan unggun $105 \mathrm{~kg} / \mathrm{m}^{3}$ akan menghasilkan temperatur yang terus meningkat disebabkan karena semakin banyak gas tertahan di dalam unggun sekam padi. Kerapatan yang besar akan membutuhkan laju udara yang tinggi pula agar mendorong gas yang tertahan karena proses pembakaran arang masih tersisa, sehingga kerapatan unggun rendah dapat menghasilkan kondisi optimal pada kondisi lubang udara tertutup.

\section{Pengaruh Tinggi Unggun}

Profil temperatur gas hasil bakar untuk variasi tinggi unggun diperlihatkan pada Gambar 5 dengan kerapatan unggun tetap sebesar $105 \mathrm{~kg} / \mathrm{m}^{3}$. Pada tinggi unggun $25 \mathrm{~cm}$ terlihat lebih cepat mencapai temperatur di atas $500{ }^{\circ} \mathrm{C}$ karena jarak antar zona di dalam reaktor gasifikasi tidak terlalu jauh. Tetapi temperatur di atas $500{ }^{\circ} \mathrm{C}$ dapat dicapai pada kondisi tinggi unggun 40 dan $50 \mathrm{~cm}$ lebih lama sehingga tinggi unggun sangat berpengaruh terhadap awal dari gas produser yang dihasilkan. Lama waktu tahan temperatur di atas $500{ }^{\circ} \mathrm{C}$ untuk seluruh variasi tinggi unggun relatif tinggi di atas 800 detik. Tetapi pada tinggi unggun 40 dan 50 $\mathrm{cm}$ masih terlihat ada kenaikan temperatur setelah terjadi penurunan temperatur. Kondisi ini diduga dari proses pembakaran arang sekam padi yang masih tersisa. Selain itu kerapatan unggun yang besar akan makin menyulitkan gas dan panas untuk melewati unggun yang lebih tinggi.

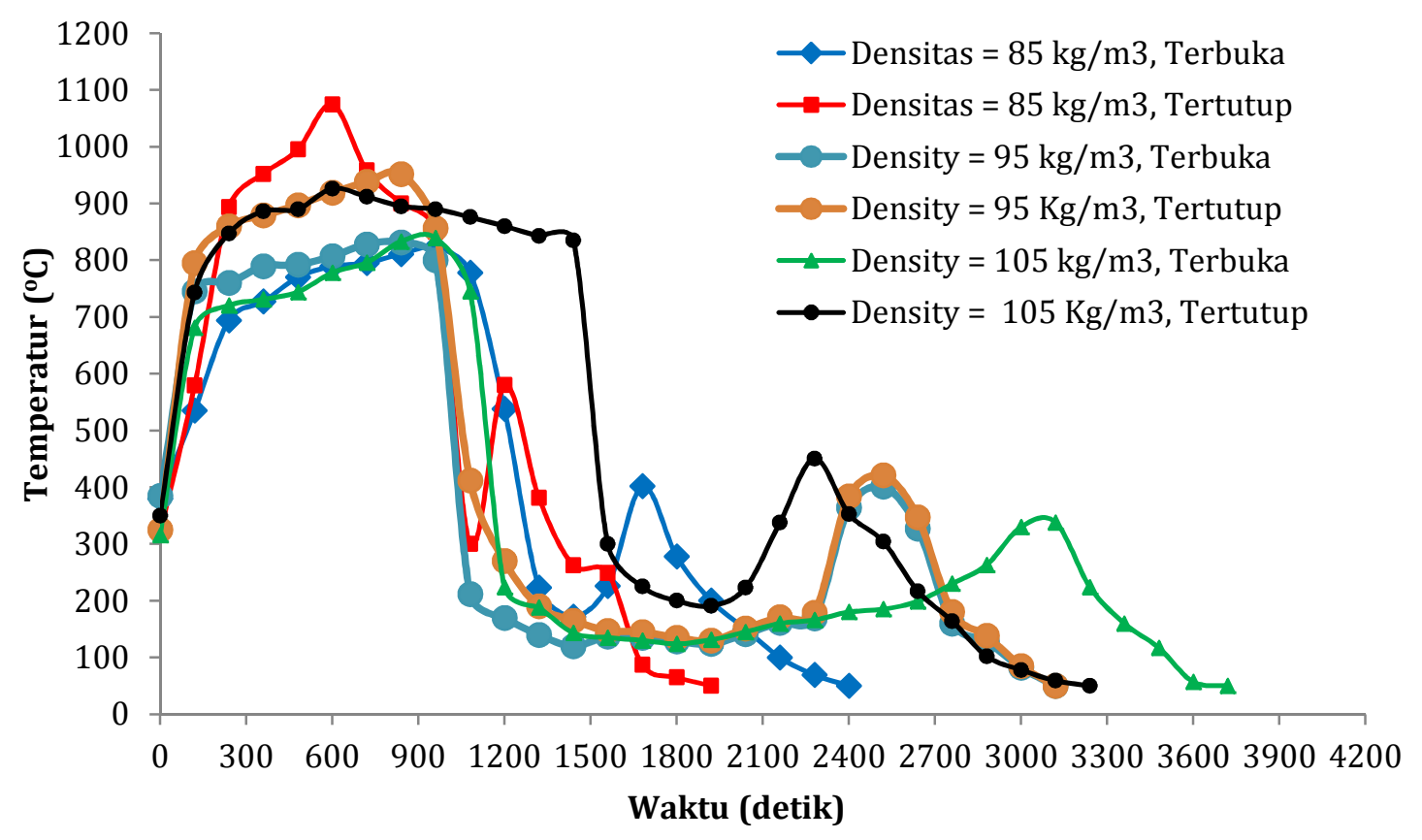

Gambar 4. Profil temperatur pembakaran gas produser dengan tinggi unggun $=40 \mathrm{~cm}$ pada variasi kerapatan 85, 95, dan $105 \mathrm{~kg} / \mathrm{m}^{3}$ pada kondisi udara pembakaran terbuka dan tertutup 


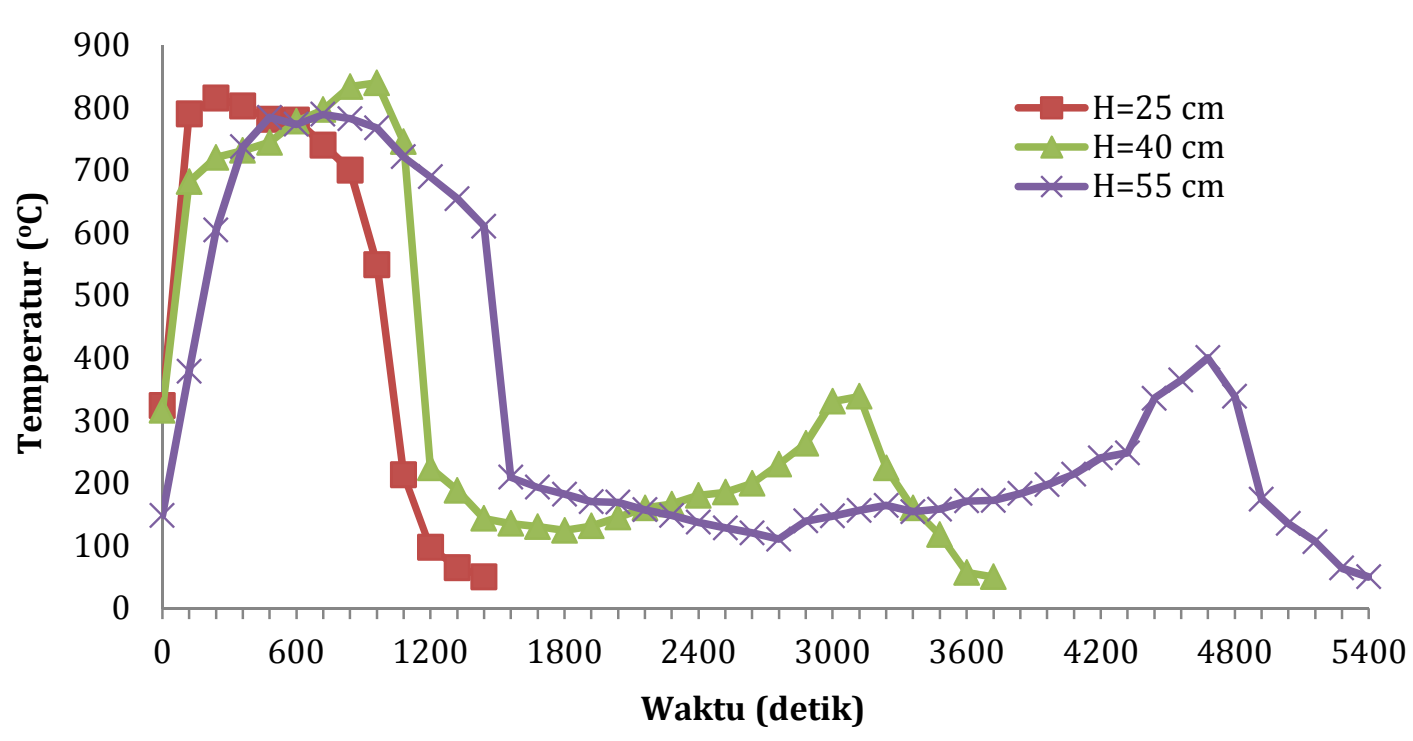

Gambar 5. Profil temperatur pembakaran gas produser pada kerapatan unggun $105 \mathrm{~kg} / \mathrm{m}^{3}$ dengan variasi tinggi unggun 25,40 , dan $55 \mathrm{~cm}$ pada kondisi udara pembakaran terbuka

Tabel 2. Laju Konsumsi Sekam Padi untuk Berbagai Variasi Tinggi Unggun dan Kerapatan

\begin{tabular}{llrlrrr}
\hline $\begin{array}{l}\text { Tinggi } \\
\text { (cm) }\end{array}$ & $\begin{array}{l}\text { Kerapatan } \\
\text { (kg/m } \mathbf{m} \text { ) }\end{array}$ & $\begin{array}{l}\text { Massa } \\
\text { Umpan } \\
\text { (g) }\end{array}$ & $\begin{array}{l}\text { Lama } \\
\text { T }_{\mathbf{5 0 0}} \\
\text { (detik) }\end{array}$ & $\begin{array}{l}\text { Massa } \\
\text { Akhir } \\
\text { (g) }\end{array}$ & \% Sisa & $\begin{array}{l}\text { Laju Konsumsi } \\
\text { Sekam Padi } \\
\text { (g/detik) }\end{array}$ \\
\hline 25 & 85 & 394 & 480 & 94 & 23,86 & 0,63 \\
25 & 95 & 420 & 480 & 98 & 23,33 & 0,67 \\
25 & 105 & 464 & 720 & 110 & 23,71 & 0,49 \\
40 & 85 & 598 & 1080 & 146 & 24,41 & 0,42 \\
40 & 95 & 671,2 & 840 & 172 & 25,63 & 0,59 \\
40 & 105 & 742 & 960 & 184 & 24,80 & 0,58 \\
55 & 85 & 822 & 1440 & 188 & 22,87 & 0,44 \\
55 & 95 & 922 & 1320 & 222 & 24,08 & 0,53 \\
55 & 105 & 1020 & 1320 & 234 & 22,94 & 0,60 \\
\hline
\end{tabular}

Hasil pengukuran temperatur untuk variasi kerapatan dan tinggi unggun dapat dilihat juga pada Tabel 2. Laju konsumsi sekam padi untuk menghasilkan temperatur di atas $500^{\circ} \mathrm{C}$ pada kerapatan $85 \mathrm{~kg} / \mathrm{m}^{3}$ lebih baik dibandingkan kerapatan 95 dan 105 $\mathrm{kg} / \mathrm{m}^{3}$. Hal ini disebabkan oleh keseimbangan antara perpindahan panas untuk masingmasing zona pada kerapatan $85 \mathrm{~kg} / \mathrm{m}^{3}$ lebih baik dibandingkan pada kerapatan 95 dan 105 $\mathrm{kg} / \mathrm{m}^{3}$ khususnya pada tinggi $40 \mathrm{~cm}$ karena mampu memberikan temperatur tinggi dalam waktu yang lama dengan konsumsi massa yang lebih sedikit dibandingkan dengan tinggi unggun $50 \mathrm{~cm}$ yaitu laju konsumsi massa sekam padi sebesar $0.42 \mathrm{~g} /$ detik.

\section{KESIMPULAN}

Dari penelitian ini dapat disimpulkan bahwa kerapatan dan tinggi unggun sangat berpengaruh terhadap proses perpindahan panas zona oksidasi terhadap zona-zona lain di dalam proses gasifikasi. Laju konsumsi massa pada tinggi unggun rendah akan lebih baik pada kerapatan unggun besar sedangkan pada unggun yang tinggi akan lebih baik pada kerapatan unggun kecil. unggun menjaga keseimbangan perpindahan panas serta produksi gas produser di antara zona-zona yang ada di kompor gasifikasi sekam padi.

\section{UCAPAN TERIMA KASIH}

Penulis mengucapkan terima kasih kepada PT Indonesia Power Unit Bisnis Suralaya atas bantuan dalam analisis proksimat.

\section{DAFTAR PUSTAKA}

Belonio, A. T., Rice Husk Gas Stove Handbook, Department of Agricultural Engineering and Environmental Management, College of Agriculture, Central Philippine University: Iloilo City, 2005. 
Bhattacharya, S. C.; Attalage, R. A.; Leon, M. A.; Amur, G. Q.; Salam, P. A.; Thanawat, C., Potential of biomass fuel conservation in selected Asian countries, Energy Conservation and Management, 1999, 40(11), 1141-1162.

Bhattacharya, S. C.; Leon, M.A., Prospect for Biomass Gasifier for Cooking Application in Asia, Energy Field of Study, Asian Institute of Technology, 2008.

Lin, K. S.; Wang, H. P.; Lin, C. J.; Juch, C. I., A Process development for gasification of rice husk, Fuel Processing Technology, 1998, 55(3), 185-192.
Ramirez, J. J.; Martinez, J. D.; Petro, S. L.; Basic design of a fluidized bed gasifies for rice husk on a pilot scale, Latin American Applied Research, 2007, 37(4), 299-306.

Sarasuk, K.; Sajjakulnukit, B., Design of labscale two-stage rice husk gasifier, Energy Procedia, 2011, 9, 178-185.

Wu, C. Z.; Huang, H.; Zheng, S. P.; Yin, X. L., An economic analysis of biomass gasification and power generation in China, Bioresource Technology, 2002, 83(1), 65-70. 